\title{
O SUPREMO TRIBUNAL FEDERAL E A SÍNDROME DE FRANKENSTEIN NO DIREITO PREVIDENCIÁRIO: UMA SÚMULA VINCULANTE INCONSTITUCIONAL
}

\section{THE SUPREME COURT FEDERAL AND FRANKENSTEIN SYNDROME IN SOCIAL SECURITY LAW: A PRECEDENT BINDING UNCONSTITUTIONAL}

${ }^{1}$ Marco Cesar De Carvalho

\section{RESUMO}

A Constituição Federal de 1988 é omissa quanto ao inciso III, do parágrafo $4^{\circ}$, do artigo 40, prevendo o direito à aposentadoria especial aos servidores públicos, razão pela qual o Supremo Tribunal Federal editou a Súmula Vinculante 33, assegurando tal benefício previdenciário até que Lei Complementar o regulamente. A Previdência Social tem caráter contributivo e deve observar critérios que preservem o equilíbrio financeiro e atuarial, com regras próprias para o Regime Geral e para o Regime Próprio de Previdência Social. Este estudo está calcado na pesquisa jurisprudencial que originou a súmula e nas referências bibliográficas indicadas ao seu final.

Palavras-chave: Seguridade social, Direito previdenciário, Aposentadoria especial dos servidores públicos, Súmula vinculante 33, Inconstitucionalidade sistemática

\begin{abstract}
The Federal Constitution of 1988 is silent as to section III of paragraph 4 of article 40, providing for the right to special retirement to public servants, which is why the Supreme Court issued the Binding Precedent 33, ensuring that benefit social security until Law supplement regularly. Social Security have contributive character and should observe criteria that preserve financial and actuarial balance, with its own rules for the General Regime and the Regime Own Social Security. This study is underpinned by the jurisprudential research that originated the precedent and in the references indicated to an end.
\end{abstract}

Keywords: Social security, Social security law, Special retirement of public servants, Binding precedent 33, Unconstitutionality systematic

\footnotetext{
${ }^{1}$ Mestre em Sistema Constitucional de Garantia de Direitos pela Instituição Toledo de Ensino - ITE, São Paulo (Brasil). Professor dos Cursos de Administração, Ciências Contábeis e Direito na Libertas - Faculdades Integradas de São Sebastião do Paraíso, Minas Gerais (Brasil). E-mail: marcocesar_cdo@ hotmail.com
} 


\section{INTRODUÇÃO}

A Constituição da República Federativa do Brasil (CF/88), em seu artigo $1^{\circ}$, inciso V, estabelece como fundamento do Estado Democrático de Direito brasileiro, os valores sociais do trabalho, sendo seus objetivos fundamentais a construção de uma sociedade livre, justa e solidária, que se desenvolva erradicando a pobreza e a marginalização, reduzindo as desigualdades sociais e regionais, promovendo o bem de todos, sem preconceitos de origem, raça, sexo, cor, idade e quaisquer outras formas de discriminação, tal como estabelece o seu artigo $3^{\circ}$. A Previdência Social figura como um direito fundamental, dentre os direitos sociais (art. $\left.6^{\circ}, \mathrm{CF} / 88\right)$.

Ocorre que tanto a CF/88 quanto a legislação infraconstitucional (Leis 8.212/91 e 8.213/91) estabeleceram o custeio e os requisitos para a concessão da aposentadoria especial aos segurados do Regime Geral de Previdência Social. Dado o caráter eminentemente contributivo da Previdência Social, organizada sob a forma de regime geral, observando critérios que preservem o equilíbrio financeiro e atuarial (art. 201, CF/88), onde a aposentadoria especial é custeada pelo Seguro de Acidentes do Trabalho.

No setor público, para os servidores efetivos, há um Regime Próprio de Previdência Social (RPPS), concebido a partir da Emenda Constitucional (EC 20), de 15/12/1998, a chamada Reforma de Previdência Social, que alterou o caput do artigo 40 da CF/88, criado com o mesmo caráter contributivo e solidário, mediante contribuição do respectivo ente público, dos servidores ativos e inativos e dos pensionistas, também observando o equilíbrio financeiro e atuarial, e que previu a aposentadoria especial com a alteração da redação do $\S$

$4^{\circ}$ do artigo 40, este depois foi novamente alterado pela EC 47, de 5/7/2005, que acrescentou mais 3 incisos, onde o inciso III assegurou aos servidores titulares de cargos efetivos da União, dos Estados, do Distrito Federal e dos Municípios, incluídas suas autarquias e fundações, uma aposentadoria especial que seria concedida a servidores cujas atividades fossem exercidas sob condições especiais que prejudiquem a saúde ou a integridade física. O que o estatuto do servidor público federal (Lei 8.112, de 11/12/1990) ainda não havia previsto.

No entanto, o inciso III, do $\S 4^{\circ}$, do artigo 40 da $\mathrm{CF} / 88$ é uma norma de eficácia limitada $^{1}$, carecendo de regulamentação através de Lei Complementar até a presente data,

\footnotetext{
Entende-se como norma de eficácia limitada, porque segundo Araújo e Nunes Júnior (2016, p. 54): “não produz todos os seus efeitos de imediato, necessitando de um comportamento legislativo infraconstitucional ou da ação dos administradores para seu integral cumprimento. As normas de eficácia limitada são, portanto, normas de eficácia fraca, podendo, no entanto, ser fortalecidas pelo legislador infraconstitucional e pelo administrador público.”.
} 
impedindo, procedimentalmente, o alcance ao referido direito, decorrendo daí o presente estudo, pontuando-se criticamente a edição da Súmula Vinculante 33 pelo Supremo Tribunal Federal, que objetivou "sanar" a omissão legislativa até a promulgação da necessária Lei Complementar regulamentadora da aposentadoria especial no serviço público.

Metodologicamente, utiliza-se o método dedutivo baseado em pesquisa jurisprudencial, bem como no estudo da teoria e aprimoramento de conceitos extraídos da pesquisa bibliográfica, constituída principalmente de livros e artigos científicos, análise da legislação correlata ao tema e levantamento de posicionamentos doutrinários, onde este artigo tem por objetivo genérico pesquisar os precedentes que originaram a edição da Súmula Vinculante 33, e como objetivo específico analisar se ela feriu os princípios constitucionais da Separação dos Poderes (art. $2^{\circ}, \mathrm{CF} / 88$ ), da precedência de custeio ou contrapartida, do o equilíbrio financeiro e atuarial que deve nortear o RPPS (art. 40, caput, CF/88), e também o próprio Sistema da Seguridade Social brasileira, em claro ativismo judicial.

Esta é a pesquisa e o trabalho que serão demonstrados a seguir.

\section{A ORIGEM DA APOSENTADORIA ESPECIAL, SEU CUSTEIO PÚblico, O PRINCÍPIO DA CONTRAPARTIDA E O EQUILÍBRIO FINANCEIRO E ATUAL DO SISTEMA PREVIDENCIÁRIO}

A Lei 3.807, de 26/8/1960, tratou da Lei Orgânica da Previdência Social (LOPS), foi o primeiro a prever a aposentadoria especial para os segurados da Previdência Social (art. 22, I, "d"), onde os serviços eram considerados penosos, insalubres ou perigosos, estando ela definida no seu artigo $31^{2}$.

Posteriormente, a Lei 5.890, de 8/6/1973, alterou a LOPS, passando a disciplinar a aposentadoria especial (art. $9^{\circ 3}$ ). Depois, a Lei 8.213, de 24/7/1991 (PBPS), passou a regular a aposentadoria especial (arts. 57/58), regulamentada pelos artigos 64/70 do Decreto 3.048/99

\footnotetext{
${ }^{2}$ Da Aposentadoria Especial

Art. 31. A aposentadoria especial será concedida ao segurado que, contando no mínimo 50 (cinqüenta) anos de idade e 15 (quinze) anos de contribuições tenha trabalhado durante 15 (quinze), 20 (vinte) ou 25 (vinte e cinco) anos pelo menos, conforme a atividade profissional, em serviços, que, para êsse efeito, forem considerados penosos, insalubres ou perigosos, por Decreto do Poder Executivo. [...]

${ }^{3}$ Art. $9^{\circ}$ A aposentadoria especial será concedida ao segurado que, contando no mínimo 5 (cinco) anos de contribuição, tenha trabalhado durante 15 (quinze), 20 (vinte) ou 25 (vinte e cinco) anos pelo menos, conforme a atividade profissional, em serviços que, para esse efeito, forem considerados penosos, insalubres ou perigosos, por decreto do Poder Executivo. [...]
} 
(RPS). Até então agentes penosos, insalubres ou perigosos garantiam a aposentadoria especial, porém, a Lei 9.032, de 28/4/1995 mudou o paradigma e excluiu os agentes penosos ou perigosos para a sua concessão (art. $3^{\circ}$ ), alterando a redação do artigo $57^{4}$ da Lei 8.213/91. Desde então, somente agentes nocivos químicos, físicos, biológicos ou associação de agentes prejudiciais à saúde ou à integridade física do segurado, pelo período equivalente ao exigido para a concessão do benefício, dão direito ao benefício previdenciário. Mas para isto, o seu custeio já estava previsto no art. $7^{\circ}, \mathrm{XXVIII,} \mathrm{da} \mathrm{CF} / 88$, sob a figura do "seguro contra acidentes de trabalho, a cargo do empregador, sem excluir a indenização a que este está obrigado, quando incorrer em dolo ou culpa;", e no artigo 22, II, da Lei 8.212, de 24/7/1991 (PCPS), previu a contribuição social a cargo da empresa, destinada à Seguridade Social para o financiamento da aposentadoria especial ao segurado que tiver trabalhado sujeito a condições especiais que prejudiquem a saúde ou a integridade física, e dos benefícios concedidos em razão do grau de incidência de incapacidade laborativa decorrente dos riscos ambientais do trabalho ( $1 \%$ onde o risco de acidentes seja leve, $2 \%$ médio e $3 \%$ para risco grave).

A chamada regra da contrapartida ou da precedência de custeio (HORVATH JÚNIOR, 2008, p. 98) ou também o princípio da precedência da fonte de custeio (CASTRO e LAZZARI, 2008, p. 101) como é denominado, estão estabelecidos no $§ 5^{\circ}$ do artigo 195 da CF/88, sendo uma regra de ouro de todo sistema previdenciário contributivo, como é o nosso, inspirado em Otto Von Bismarck, já que o acesso aos benefícios exige prévia contribuição: "§

$5^{\circ}$ Nenhum benefício ou serviço da seguridade social poderá ser criado, majorado ou estendido sem a correspondente fonte de custeio total.".

Segundo Balera, a regra de contrapartida, tanto do RGPS quanto no RPPS, revela o cuidado do legislador quanto à manutenção do equilíbrio financeiro do sistema, dando uma lógica a ele, ou seja, sem a respectiva fonte de custeio não há benefício, o equilíbrio dos sistemas previdenciários contributivos advém daí: "a consequência natural de que posta a fonte de custeio já está criado o benefício”, apontando (2012, p. 83) que:

\footnotetext{
${ }^{4}$ Da Aposentadoria Especial

Art. 57. A aposentadoria especial será devida, uma vez cumprida a carência exigida nesta Lei, ao segurado que tiver trabalhado sujeito a condições especiais que prejudiquem a saúde ou a integridade física, durante 15 (quinze), 20 (vinte) ou 25 (vinte e cinco) anos, conforme dispuser a lei. [...]

$\S 3^{\circ}$ A concessão da aposentadoria especial dependerá de comprovação pelo segurado, perante o Instituto Nacional do Seguro Social - INSS, do tempo de trabalho permanente, não ocasional nem intermitente, em condições especiais que prejudiquem a saúde ou a integridade física, durante o período mínimo fixado.

$\S 4^{\circ} \mathrm{O}$ segurado deverá comprovar, além do tempo de trabalho, exposição aos agentes nocivos químicos, físicos, biológicos ou associação de agentes prejudiciais à saúde ou à integridade física, pelo período equivalente ao exigido para a concessão do benefício. [...]
} 
A regra da contrapartida, sendo essencial ao funcionamento da seguridade social, toda ela baseada na ideia do equilíbrio financeiro e atuarial, poderia estar bem situada no catálogo dos princípios.

Se a lei ignora as exigências da regra da contrapartida, fica em perigo todo o planejamento engendrado pelo Plano de Custeio.

É de tal importância esta regra, que sem ela não há sistema previdenciário que perdure, porque o financiamento da Previdência Social não pode vir do Governo, mas sim dos próprios segurados deste sistema, onde Castro e Lazzari (2008, pp. 101-102) consideram a regra como um verdadeiro princípio:

Trata-se de princípio, pois nenhuma norma legal poderá violar tal preceito, sob pena de inconstitucionalidade. [...]

A observância deste princípio é de fundamental importância para que a Previdência Social pública se mantenha em condições de conceder as prestações previstas, sob pena de, em curto espaço de tempo, estarem os segurados definitivamente sujeitos à privatização de tal atividade, em face da incapacidade do Poder Público em gerar mais receita para cobertura de déficits.

Mesma posição de Martins (2012, p. 17) para quem: “Assim, há necessidade de que primeiro exista a fonte de custeio para depois ser criado o benefício.". Por óbvio que o citado Plano de Custeio é o retratado na Lei 8.212/1991 (artigo 22, II) no tocante ao RGPS, porque nos RPPS ainda não foi criada a sua fonte de custeio, porém, tal como assentou o artigo 40 caput da CF/88, a partir da EC 20/1998, objetiva-se também o equilíbrio financeiro e atuarial dos RPPS. Torraca (2010, p. 1) conceitua o equilíbrio financeiro como:

o saldo zero ou positivo do encontro entre as receitas e a despesa do sistema. É a adequada arrecadação dos valores a serem pagos ao sistema e a realização de todos os pagamentos devidos, ou seja, o pagamento de todos os benefícios previdenciários a que fazem jus os indivíduos.

$\mathrm{O}$ equilíbrio financeiro consiste em depois de realizada a arrecadação e feitos os pagamentos, não haver saldo negativo nos fundos previdenciários, evitando danos às contas públicas.

Já o conceito de atuarial advém da ciência do seguro, onde Torraca (2010, pp. 1-2) ensina que:

\begin{abstract}
Atuarial é a ciência dedicada aos cálculos feitos pelas companhias de seguro de vida, estabelecendo as bases de suas operações e verificando os resultados, ou seja, é calculado o risco protegido e os recursos para sua cobertura, vislumbrando as possibilidades em variadas situações, no caso do sistema previdenciário, especialmente dentro das expectativas futuras em relação ao envelhecimento da população e às tendências da natalidade populacional.
\end{abstract}

Incumbe aos administradores dos RPPS, através das análises atuárias, elaborar medidas para a correção de desvios, como por exemplo, o aumento da natalidade, da expectativa de vida dos segurados, para que o sistema continue protegido, mantendo sempre seu equilíbrio financeiro, o que segundo Castro e Lazzari (2008, p. 104) significa: 
que o Poder Público deverá, na execução da política previdenciária, atentar sempre para a relação entre custeio e pagamento de benefícios, a fim de manter o sistema em condições superavitárias, e observar as oscilações da medida etária da população, bem como sua expectativa de vida, para a adequação dos benefícios a estas variáveis. [...]

Em um sistema de repartição simples como o brasileiro, o elemento fundamental para manter seu equilíbrio, considerando-se somente as variáveis demográficas, é a estrutura etária da população em cada momento, pois é ela que define a relação entre beneficiários (população idosa) e contribuintes (população em idade ativa).

A aposentadoria especial surgiu para os servidores públicos efetivos a partir da EC 20/1998, que alterou a redação do tanto do caput quanto do $\S 4^{\circ}$ do artigo 40, da CF/88, para também estabelecer um Regime Próprio de Previdência Social, com caráter contributivo e solidário, mediante contribuição do respectivo ente público, dos servidores ativos e inativos e dos pensionistas, onde está definido que, tal qual o RGPS, os RPPS devem observar o mesmo equilíbrio financeiro e atuarial, porém, para eles, a Lei 8.112, de 11/12/1990, que dispunha sobre o regime jurídico dos Servidores Públicos Civis da União, das autarquias e das fundações públicas federais (art. $183^{5}$ ), não previa a especial dentre as aposentadorias (art. 185, I c/c 186), portanto, também não compunha o cálculo atuarial e financeiro nem compunha o custeio estabelecido (art. 231), o qual, desde a Lei 10.887, de 18/6/2004, previa a contribuição social do servidor público federal, em $11 \%$ (art. $4^{\circ}$ ) e o dobro para a União (art. $8^{\circ}$ ), com responsabilidade solidária desta por eventuais insuficiências financeiras.

Com a EC 20/1998 passando a prever a aposentadoria especial, ela já estabeleceu em seu artigo 15 que: “Art. 15. Até que a lei complementar a que se refere o art. 201, § $1^{\circ}$, da Constituição Federal, seja publicada, permanece em vigor o disposto nos arts. 57 e 58 da Lei n ${ }^{\circ}$ 8.213, de 24 de julho de 1991, na redação, vigente à data da publicação desta Emenda.”, o que teria sido a maneira criada até que a citada Lei Complementar fosse editada, impedindo o gozo de tal direito pelos seus respectivos titulares. Já para as pessoas com deficiência, no RGPS, foi editada a Lei Complementar 142, de 8/5/2013.

No entanto, o parágrafo único do artigo $5^{\circ}$ da Lei 9.717 , de 27/11/1998, que dispôs sobre as regras gerais para a organização e o funcionamento dos RPPS dos servidores públicos das 3 esferas de poder, já ressaltava a imprescindibilidade da lei complementar:

Art. $5^{\circ}$ Os regimes próprios de previdência social dos servidores públicos da União, dos Estados, do Distrito Federal e dos Municípios, dos militares dos Estados e do Distrito Federal não poderão conceder benefícios distintos dos previstos no Regime Geral de Previdência Social, de que trata a Lei $n^{\circ} 8.213$, de 24 de julho de 1991, salvo disposição em contrário da Constituição Federal.

Parágrafo único. Fica vedada a concessão de aposentadoria especial, nos termos do $\S$

\footnotetext{
${ }^{5}$ Art. 183. A União manterá Plano de Seguridade Social para o servidor e sua família.
} 
$\underline{4^{\circ} \text { do art. } 40 \text { da Constituição Federal, até que lei complementar federal discipline a }}$ matéria. (grifo nosso)

Portanto, para os RPPS, a Lei Complementar federal é mesmo imprescindível, conforme o $\S 4^{\circ}$ do artigo 40 da CF/88 combinado com o artigo 146, III, da CF/88. E esta interpretação sistemática e teleológica mostra que a Constituição Federal deve ser respeitada e interpretada como um todo, e não interpretada em fatias!

Mas Campos (2012, p. 243) critica tal dispositivo legal, sob o fundamento de que às leis estaduais caberiam dispor sobre normas suplementares acerca da aposentadoria especial dos servidores até que as normas gerais advenham, e que os Municípios também poderiam legislar sobre os seus RPPS, nos mesmos limites que os Estados, assim:

Entendo absolutamente inconstitucional o disposto no art. $5^{\circ}$, parágrafo único, da Lei 9.717/98, incluído pela Medida Provisória 2.1871-13/01, que veda a concessão de aposentadoria especial, nos termos do $\S 4^{\circ}$ do art. 40 da Constituição Federal, até que lei complementar federal discipline a matéria, isto porque é flagrante a ofensa ao art. 24 , XII e seus $\S \S 1^{\circ}$ ao $4^{\circ}$, da Constituição de 1988 , conforme demonstrado.

Pois é, inexistindo norma geral editada pela União, os Estados (art. 24, XII, § $3^{\circ}$, $\mathrm{CF} / 88$ ) e até os Municípios (art. 30, II, CF/88) poderiam ter legislado suplementarmente até que a União estabelecesse as normas gerais, que uniformizariam o tema especialmente no tocante às exceções para as aposentadorias. Mas já há uma lei federal - Lei 9.717, de 27/11/1998 - onde o parágrafo único do seu artigo $5^{\circ}$ veda expressamente a concessão da aposentadoria especial pelos RPPS aos servidores públicos de toda a administração pública.

Assim, e até então, prevalecia a diretriz do $\S 4^{\circ}$ do artigo 40 da $\mathrm{CF} / 88$, que previu a aposentadoria especial para os servidores públicos, mas dependente de Lei Complementar regulamentadora, e o próprio caput do artigo 40 de nossa Constituição Federal que estabeleceu um RPPS com critérios que observem o equilíbrio financeiro e atuarial. No entanto, vejamos como o STF decidiu a questão da falta de norma regulamentadora para a fruição de tal direito nos RPPS.

\section{A CONSTRUÇÃO JURISPRUDENCIAL DA EXTENSÃO DA APOSENTADORIA ESPECIAL AOS SERVIDORES PÚBLICOS E A SUPERAÇÃO DO PRINCÍPIO DA CONTRAPARTIDA}

Garantida desde a LOPS, a aposentadoria especial era concebida apenas para os segurados do RGPS, assim, por razão eminentemente discriminatória, já que se defende aqui ser tal desequiparação ou discrímen, totalmente desarrazoada, isto porque desde sempre existiram servidores públicos titulares de cargos efetivos cujas funções eram exercidas sob 
condições tais que prejudicavam sua saúde ou sua integridade física. Mas estes servidores não tinham igual tutela, o que perdurou até a EC 20, de 15/12/1998, já que na origem do artigo 40 da $\mathrm{CF} / 88$, também não se previa a aposentadoria especial aos servidores públicos. A partir da EC 20/1998, ficou assim redigido:

Art. 40. Aos servidores titulares de cargos efetivos da União, dos Estados, do Distrito Federal e dos Municípios, incluídas suas autarquias e fundações, é assegurado regime de previdência de caráter contributivo e solidário, mediante contribuição do respectivo ente público, dos servidores ativos e inativos e dos pensionistas, observados critérios que preservem o equilíbrio financeiro e atuarial e o disposto neste artigo.

[...]

$\S 4^{\circ}$ É vedada a adoção de requisitos e critérios diferenciados para a concessão de aposentadoria aos abrangidos pelo regime de que trata este artigo, ressalvados, nos termos definidos em leis complementares, os casos de servidores:

I portadores de deficiência;

II que exerçam atividades de risco;

III cujas atividades sejam exercidas sob condições especiais que prejudiquem a saúde ou a integridade física.

A Senadora Ideli Salvatti (PT/SC), então líder do Partido dos Trabalhadores, apresentou a PEC 227/2004 ${ }^{6}$, que tratava da Reforma da Previdência para os servidores públicos, e que acabou dando origem à EC 47/2005. Mas antes disto, na Câmara dos Deputados foi apresentado um substitutivo de número 77/2003, conhecido como PEC Paralela da Previdência, concebida pelo Senador Paulo Paim (PT/RS). No Senado Federal, o relator da Reforma da Previdência, Senador Tião Viana (PT/AC), foi imposto como condição para votação da Reforma da Previdência a aprovação da PEC Paralela com regras de transição menos draconianas para os atuais servidores. A PEC Paralela promoveu modificações na Reforma da Previdência (EC 41, de 19/12/2003) para os servidores públicos de então, no que diz respeito: I) à integralidade; II) à paridade; III) à transição; IV) ao subteto; V) à contribuição de inativo; VI) à aposentadoria especial; VII) à contribuição da empresa para o INSS, e VIII) à inclusão previdenciária.

6 Disponível em: <http://www2.camara.leg.br/proposicoesWeb/fichadetramitacao?idProposicao=150399>. Acesso em: 14 fev. 2016. 
Em face da previsão do direito, mas com a falta da Lei Complementar regulamentadora do mesmo, portanto, diante de uma mora legislativa federal, e ao mesmo tempo diante do citado parágrafo único do artigo $5^{\circ}$ da Lei 9.717/98, diversos servidores públicos ingressaram com Mandados de Injunção, conforme permissivo do artigo $5^{\mathbf{o}^{7}}$, LXXI, CF/88, para sanarem a existência de norma constitucional não autoaplicável, e romperem a inércia do legislador. Assim, com base em 11 precedentes $^{8}$, o STF, em 24/4/2014, editou a Súmula Vinculante número 33, prevendo:

Aplicam-se ao servidor público, no que couber, as regras do regime geral da previdência social sobre aposentadoria especial de que trata o artigo $40, \S 4^{\circ}$, inciso III da Constituição Federal, até a edição de lei complementar específica. (DOU 24.4.2014 e DJe-STF 24.4.2014)

Portanto, até que ocorra a edição de lei complementar a que se refere o artigo 40, § $4^{\circ}$, da CF/88, ao servidor público aplicar-se-ão as regras do RGPS (artigos 57 e 58) para a concessão da aposentadoria especial. Segundo o primeiro precedente, o Mandado de Injunção 721, impetrado no Distrito Federal, em face do Presidente da República, cuja relatoria coube ao Ministro Marco Aurélio, julgado pelo Plenário do STF em 30/8/2007, com decisão unânime acompanhando o seu voto, tem a seguinte ementa:

MANDADO DE INJUNÇÃO - NATUREZA. Conforme disposto no inciso LXXI do artigo $5^{\circ}$ da Constituição Federal, conceder-se-á mandado de injunção quando necessário ao exercício dos direitos e liberdades constitucionais e das prerrogativas inerentes à nacionalidade, à soberania e à cidadania. Há ação mandamental e não simplesmente declaratória de omissão. A carga de declaração não é objeto da impetração, mas premissa da ordem a ser formalizada. MANDADO DE INJUNÇÃO - DECISÃO - BALIZAS. Tratando-se de processo subjetivo, a decisão possui eficácia considerada a relação jurídica nele revelada. APOSENTADORIA TRABALHO EM CONDIÇÕES ESPECIAIS - PREJUÍZO À SAÚDE DO SERVIDOR - INEXISTÊNCIA DE LEI COMPLEMENTAR - ARTIGO 40, § $4^{\circ}$, DA CONSTITUIÇÃO FEDERAL. Inexistente a disciplina específica da aposentadoria especial do servidor, impõe-se a adoção, via pronunciamento judicial, daquela própria aos trabalhadores em geral - artigo $57, \S 1^{\circ}$, da Lei $n^{\circ} 8.213 / 91$.

\footnotetext{
${ }^{7}{ }^{7}$ DOS DIREITOS E GARANTIAS FUNDAMENTAIS CAPÍTULO I - DOS DIREITOS E DEVERES INDIVIDUAIS E COLETIVOS

Art. $5^{\circ}$ Todos são iguais perante a lei, sem distinção de qualquer natureza, garantindo-se aos brasileiros e aos estrangeiros residentes no País a inviolabilidade do direito à vida, à liberdade, à igualdade, à segurança e à propriedade, nos termos seguintes: [...]

LXXI - conceder-se-á mandado de injunção sempre que a falta de norma regulamentadora torne inviável o exercício dos direitos e liberdades constitucionais e das prerrogativas inerentes à nacionalidade, à soberania e à cidadania;

${ }^{8}$ Precedentes: MI 721/DF, rel. Min. Marco Aurélio, Tribunal Pleno, DJ de 30/11/.2007; MI 795/DF, rel. Min. Cármen Lúcia, Tribunal Pleno, DJ de 22/05/2009; MI 788/DF, rel. Min. Ayres Britto, Tribunal Pleno, DJ de 08/05/2009; MI 925/DF, rel. Min. Cezar Peluso, DJ de 23/06/2009; MI 1.328/DF, rel. Min. Ricardo Lewandowski, DJ de 1\%/02/2010; MI 1.527/DF, rel. Min. Eros Grau, DJ de 05/03/2010; MI 2.120/DF, rel. Min. Joaquim Barbosa, DJ de 24/03/2010; MI 1.785/DF, rel. Min. Ellen Gracie, DJ de 29/03/2010; MI 4.158 AgR- segundo/MT, rel. Min. Luiz Fux, Tribunal Pleno, DJ de 19/02/2014; MI 1.596 AgR/DF, rel. Min. Cármen Lúcia, Tribunal Pleno, DJ de 31/05/2013; MI 3.215 AgR-segundo/DF, rel. Min. Celso de Mello, Tribunal Pleno, DJ de 10/06/2013.
} 
A ratio decidendi deste MI 721/DF, extrai-se do voto do Ministro Marco Aurélio ${ }^{9}$, onde:

- a natureza do Mandado de Injunção leva o pronunciamento a ganhar contornos mandamentais;

- que o STF era tímido inicialmente quanto ao alcance do MI, em face da separação e harmonia entre os poderes, quando o pronunciamento era meramente declaratório de ato omissivo do Poder Legislativo;

- e que a função do Poder Judiciário é exatamente afastar as consequências da mora legislativa, em processo subjetivo, dado que as normas definidoras de direitos e garantias individuais têm aplicabilidade imediata;

- por fim, que seria possível adotar o mesmo critério da concessão da aposentadoria especial do RGPS ao RPPS.

Registra-se que a Procuradoria Geral da República era contrária ao cabimento do Mandado de Injunção sob a alegação de que o artigo 40, $\S 4^{\circ}$, da $C F / 88$ não criava direito subjetivo à aposentadoria, porque inexiste obrigatoriedade do legislador derivado em editar a norma regulamentadora, o que se traduziria numa mera faculdade do Poder Legislativo, mormente diante do juízo político de conveniência e oportunidade que não pode ser substituído pela forca da decisão judicial, o que resultaria em invasão desautorizada da esfera de atuação dos demais Poderes da República.

O segundo precedente originário da súmula vinculante, foi o $\mathrm{MI} 795 / \mathrm{DF}^{10}$, julgado pelo Plenário do STF em 15/4/2009, mostrando que a Procuradoria Geral da República mudou seu entendimento pela procedência da impetração e quando a Relatora Ministra Cármen Lúcia reassentou a mora legislativa autorizadora do Poder Judiciário de atuar de forma a viabilizar a imediata aplicação do direito à aposentadoria especial ao caso concreto, desde que comprovados os dados perante a autoridade administrativa competente conforme exige o artigo 57 da Lei 8.213/91. Neste julgamento foi levantada questão de ordem pelo Ministro Joaquim Barbosa, tendo o STF autorizado que os Ministros decidissem os casos idênticos, a partir de então, monocrática e definitivamente.

O MI 788/DF ${ }^{11}$, igualmente julgado pelo Plenário do STF em 15/4/2009, foi o primeiro onde o Advogado Geral da União sustentou que tal concessão ofenderia os princípios constitucionais da isonomia, precedência de custeio e do equilíbrio financeiro e atuarial, mas o Relator Ministro Carlos Ayres Britto reafirmou seu voto naquele MI 721/DF, sem ter analisado a ofensa aos citados princípios constitucionais apontados pela AGU. Já no MI 925/DF ${ }^{12}$, julgado monocraticamente pelo Relator Ministro Cezar Peluso, em 17/6/2009,

\footnotetext{
9 Disponível em: <http://redir.stf.jus.br/paginadorpub/paginador.jsp?docTP=AC\&docID=497390>. Acesso em: 26 mar. 2016.

${ }^{10}$ Disponível em: <http://redir.stf.jus.br/paginadorpub/paginador.jsp?docTP=AC\&docID=593668>. Acesso em: 26 mar. 2016.

11 Disponível em: <http://redir.stf.jus.br/paginadorpub/paginador.jsp?docTP=AC\&docID=591237>. Acesso em: 26 mar. 2016.

${ }^{12}$ Disponível em: <http://www.stf.jus.br/portal/jurisprudencia/listarJurisprudencia.asp?s1=\%28MI\%24\%2ESCLA\%2E+E+925\%2 ENUME\%2E\%29+NAO+S\%2EPRES\%2E\&base=baseMonocraticas\&url=http://tinyurl.com/p3xtosf >. Acesso em: 26 mar. 2016.
} 
foi enfrentada a questão suscitada de ofensa ao princípio constitucional da precedência de custeio, com a seguinte fundamentação:

\begin{abstract}
A União trouxe, no entanto, nova questão. Alega que, ante a natureza normativa da decisão em sede de mandado de injunção e da exigência constitucional de estabelecimento prévio de fonte de custeio para novas contribuições, deva ser essa indicada.

Argúi inconstitucionalidade da norma jurídica expedida para o caso concreto, por afronta ao art. 195 da Constituição Federal.

Em primeiro plano, analiso a forma de custeio da aposentadoria especial no regime geral de previdência.

Dispõe o $§ 6^{\circ}$ do art. 57 da Lei $\mathrm{n}^{\circ} 8.213$, de 24 de julho de 1991, que a aposentadoria especial será custeada pela contribuição prevista no inciso II do art. 22 da Lei ${ }^{\circ}$ 8.212, de 24 de julho de 1991, que, por sua vez, estabelece uma contribuição social devida pela empresa na qual trabalhadores são expostos a riscos ambientais.

Trata-se de benefício custeado unicamente pelo empregador. Tal sistema é dotado de razoabilidade.

Não se poderia pretender que o trabalhador, que tem o direito de se aposentar contando de tempo especial - em virtude das condições adversas em que exerceu o seu cargo -, arque com o custeio dessa modalidade de aposentadoria.

Na questão suscitada pela União quanto à fonte de custeio da aposentadoria especial "criada pelo Supremo Tribunal Federal", até por isonomia não poderá haver solução diversa.

O responsável pelo custeio do benefício especial deverá ser o Estado, porque isso é o que se ajusta ao caput do art. 40 da Constituição Federal, que estabelece o regime previdenciário público "mediante contribuição do respectivo ente público".

A fonte de custeio da aposentadoria especial dos funcionários públicos deverá ser, pois, a "contribuição" dos entes públicos aos quais são vinculados.

3. Dessa forma, concedo a ordem, para garantir o direito dos substituídos processuais à aposentadoria especial, que deverá ter o pedido analisado pelo órgão competente, à luz do disposto nos arts. 57 e 58 da Lei no 8.213 , de 24 de julho de 1991, nos termos dos precedentes desta Corte.
\end{abstract}

É fato que a aposentadoria especial no RGPS é custeada pelo empregador, através do SAT, assim o é porque desde sua criação ele já previu a contribuição do empregador (art. 22, I, da Lei 8.212/91) a que se refere o SAT, mas que não existe no RPPS, e aqui o Relator Ministro Cezar Peluso, com a mesma premissa destacou que: "A fonte de custeio da aposentadoria especial dos funcionários públicos deverá ser, pois, a "contribuição" dos entes públicos aos quais são vinculados.”, superando o princípio constitucional da contrapartida, previsto no $\S 5^{\circ}$ do artigo 195 da CF/88, assegurador da manutenção do equilíbrio financeiro e atuarial do sistema. Igualmente destacou ao Relator: "O responsável pelo custeio do benefício especial deverá ser o Estado, porque isso é o que se ajusta ao caput do art. 40 da Constituição Federal, que estabelece o regime previdenciário público "mediante contribuição do respectivo ente público", é verdade que não somente do ente público, mas deste em conjunto com os servidores ativos e inativos e dos pensionistas, observando critérios que preservem o equilíbrio financeiro e atuarial, e a questão destes critérios que não foi mencionada. 
O MI 1.328/DF ${ }^{13}$, julgado monocraticamente pelo Relator Ministro Ricardo Lewandowski, em 14/9/2009, tendo novamente a AGU sustentado que tal concessão ofenderia os princípios constitucionais da isonomia, precedência de custeio e do equilíbrio financeiro e atuarial, mas o Relator Ministro Carlos Ayres Britto reafirmou os precedentes dos MI's 721/DF e 795/DF, olvidando a análise da ofensa aos citados princípios constitucionais apontados pela AGU. O MI 1.527/DF ${ }^{14}$, julgado monocraticamente pelo Relator Ministro Eros Grau, em 24/2/2010, com parecer favorável da PGR, fundamentando que: "Importa verificarmos é se o Supremo Tribunal Federal emite decisões ineficazes; decisões que se bastam em solicitar ao Poder Legislativo que cumpra o seu dever, inutilmente.”, o qual foi julgado procedente. O MI 2.120/DF ${ }^{15}$, julgado monocraticamente pelo Relator Ministro Joaquim Barbosa, em 16/3/2010, com parecer favorável da PGR, tão somente reafirmou os precedentes dos MI's 721/DF e 795/DF, julgando procedente. O MI 1.785/DF ${ }^{16}$, julgado monocraticamente pela Relatora Ministra Ellen Gracie, em 23/3/2010, com parecer favorável da PGR, igualmente reafirmou os precedentes dos MI's 721/DF, 788/DF e 795/DF, julgando procedente.

O MI 4.158/MT ${ }^{17}$, julgado monocraticamente pelo Relator Ministro Luiz Fux, em 27/11/2012, referia-se a pessoa com deficiência que pleiteava a mesma aposentadoria especial que aqueles que estivem em condições insalubres e que o STF vinha deferindo a aplicação analógica do RGPS, julgando procedente, mas que posteriormente, em sede de Agravo Regimental $^{18}$, reconsiderou parcialmente a decisão do MI para, com a entrada em vigor da LC 142/2013, aplicar-se-lhe as respectivas normas, restando sanada a omissão legislativa. Assim também o MI 1.596/DF ${ }^{19}$, julgado monocraticamente pelo Relator Ministro Carlos Ayres Britto, em 29/11/2011, igualmente referia-se a pessoa com deficiência que pleiteava que o STF desse aplicação analógica do RGPS, foi julgado procedente, e mantido em sede de Agravo Regimental $^{20}$, julgado em 16/5/2013, reconsiderando parcialmente a decisão do MI para aplicar a LC 142/2013, restando sanada a omissão legislativa.

\footnotetext{
${ }^{13}$ Disponível em: <http://www.stf.jus.br/portal/jurisprudencia/listarJurisprudencia.asp?s1=\%28MI\%24\%2ESCLA\%2E+E+1328\% 2ENUME\%2E\%29+NAO+S\%2EPRES\%2E\&base=baseMonocraticas\&url=http://tinyurl.com/pu856uc >. Acesso em: 26 mar. 2016

${ }^{14}$ Disponível em: <http://www.stf.jus.br/portal/jurisprudencia/listarJurisprudencia.asp?s1=\%28MI\%24\%2ESCLA\%2E+E+1527\% 2ENUME\%2E\%29+NAO+S\%2EPRES\%2E\&base=baseMonocraticas\&url=http://tinyurl.com/kfxruy5>. Acesso em: 26 mar. 2016.

${ }^{15}$ Disponível em: <http://www.stf.jus.br/portal/jurisprudencia/listarJurisprudencia.asp?s1=\%28MI\%24\%2ESCLA\%2E+E+2120\% 2ENUME\%2E\%29+NAO+S\%2EPRES\%2E\&base=baseMonocraticas\&url=http://tinyurl.com/aae4pok>. Acesso em: 26 mar. 2016.

${ }^{16}$ Disponível em: <http://www.stf.jus.br/portal/jurisprudencia/listarJurisprudencia.asp?s1=\%28MI\%24\%2ESCLA\%2E+E+1785\% 2ENUME\%2E\%29+NAO+S\%2EPRES\%2E\&base=baseMonocraticas\&url=http://tinyurl.com/cdjpajt $>$. Acesso em: 26 mar. 2016.

${ }^{17}$ Disponível em: <file:///C:/Users/User/Downloads/texto_113535162\%20(1).pdf〉. Acesso em: 26 mar. 2016.

${ }^{18}$ Disponível em: <file:///C:/Users/User/Downloads/texto_173555588.pdf〉. Acesso em: 26 mar. 2016.

19 Disponível em: 〈http://www.stf.jus.br/portal/processo/verProcessoTexto.asp?id=3087613\&tipoApp=RTF>. Acesso em: 26 mar. 2016.

20 Disponível em: <file:///C:/Users/User/Downloads/texto_143924434.pdf〉. Acesso em: 26 mar. 2016.
} 
Por fim, o MI Coletivo 3.215/DF ${ }^{21}$, julgado monocraticamente pelo Relator Ministro Celso de Mello, em 21/11/2011, reafirmou os precedentes da Corte, principalmente o MI 721/DF, julgando procedente o MI, deferindo a aplicação analógica do RGPS, o que foi mantido em sede de Agravo Regimental ${ }^{22}$, julgado em 24/4/2013. Destaca-se aqui:

O desprestígio da Constituição - por inércia de órgãos meramente constituídos representa um dos mais graves aspectos da patologia constitucional, pois reflete inaceitável desprezo, por parte das instituições governamentais, da autoridade suprema da Lei Fundamental do Estado.

Portanto, nestes precedentes a preocupação precípua foi a de conferir a máxima efetivação do dispositivo constitucional que estabeleceu a aposentadoria especial para o servidor público, porém, olvidando os critérios que observem o equilíbrio financeiro e atuarial dos RPPS. Resta claro que o STF partiu do método hermenêutico tópicoproblemático $^{23}$ para a solução do caso concreto apresentado, ou seja, a redação do $\S 4^{\circ}$ do artigo 40 da $\mathrm{CF} / 88$, que exige leis complementares para definirem os requisitos e critérios diferenciados para a concessão da aposentadoria especial dos servidores públicos.

A crítica para tal método hermenêutico, que também serve de argumento neste trabalho, é no sentido de que houve um casuísmo porque a interpretação deveria partir das normas previdenciárias como um todo para o problema, sistematicamente, de maneira que todo o sistema previdenciário seja preservado. Mas tais decisões que subsidiaram a elaboração da Súmula Vinculante 33 do STF acabaram por ferir outros métodos interpretativos constitucionais, principalmente o da Constituição como integridade, já que, sistematicamente, não se pode conceder, estender ou majorar princípio sem a respectiva fonte de custeio total ( $\S$ $5^{\circ}$, artigo 195 , da $\mathrm{CF} / 88$ ).

Se a regra ou "princípio da contrapartida" foi superada jurisprudencialmente naquele MI 925/DF, restaram olvidados os critérios que observem o equilíbrio financeiro e atuarial dos RPPS. E estes critérios têm um sentido maior que unicamente a concessão de benefícios previdenciários a certos segurados, têm uma preocupação com a manutenção de todo um sistema e regime previdenciários, para a segurança de todos os segurados.

21 Disponível em: <http://www.stf.jus.br/portal/processo/verProcessoTexto.asp?id=3081133\&tipoApp=RTF>. Acesso em: 26 mar. 2016.

${ }^{22}$ Disponível em: <file:///C:/Users/User/Downloads/texto_145873067\%20(1).pdf>. Acesso em: 26 mar. 2016.

${ }^{23} \mathrm{O}$ método tópico foi desenvolvido pelos juristas alemães Theodor Viehweg e Josef Esser, sendo que a primeira obra sobre o assunto, denominada "Tópica e Jurisprudência", de autoria de Viehweg, foi publicada em 1953. O método tópico caracteriza-se como uma "arte de invenção" e, como tal, uma "técnica de pensar o problema", elegendo-se o critério ou os critérios recomendáveis para uma solução adequada. In: VIEHWEG, Theodor. Tópica e jurisprudência: uma contribuição à investigação dos fundamentos jurídico-científicos. Tradução da 5 . ed. Alemã, rev. e ampl., de Prof ${ }^{a}$ Kelly Susane Alflen da Silva. Porto Alegre: Sergio Antonio Fabris Ed., 2008. 
É justa a aflição dos servidores públicos que aguardam a regulamentação de sua aposentadoria especial pelo Congresso Nacional, mas é mais importante preservar a integridade do sistema previdenciário como um todo, porque se se concede benefício sem a observância a tais critérios, num futuro breve, não haverá recursos para pagar todos os benefícios aos seus segurados. Nem se trata de alegar a reserva do possível.

O problema central que se coloca neste trabalho é: pode tal Súmula Vinculante 33 assegurar aos servidores públicos sua aposentadoria especial sem o respeito a critérios de equilíbrio financeiro e atuarial dos RPPS? Como fica o equilíbrio atuarial e financeiro de tal sistema? Poderá haver um desequilíbrio de todo o sistema, podendo inclusive inviabilizar sua sustentabilidade?

De início e para tais respostas é imprescindível afirmar que a decisão de um Mandado de Injunção não autoriza o Poder Judiciário suprir a omissão legislativa ou regulamentar, editando o ato normativo omitido, nem lhe permite ordenar um ato concreto de satisfação do direito reclamado, isto porque o STF tão somente deveria cientificar o Congresso Nacional para que suprisse a tal omissão, evidenciando o seu ativismo judicial ${ }^{24}$.

\section{O PRINCÍPIO DA MÁXIMA EFICÁCIA DAS NORMAS CONSTITUCIONAIS E A MANUTENÇÃo DE UM SISTEMA PREVIDENCIÁRIO EQUILIBRADO}

O princípio da máxima eficácia das normas definidoras dos direitos e garantias constitucionais se infere da interpretação do $\S 1^{\circ}$ do artigo $5^{\circ}$, da $\mathrm{CF} / 88$, e dentre os direitos sociais elencados no artigo $6^{\circ}$, está a Previdência Social. Para os servidores públicos, o RPPS é quem lhes confere o direito à sua previdência, sob determinadas regras. Dimoulis e Martins (2012, pp. 91/92) reafirmam que:

\footnotetext{
${ }^{24}$ Segundo Barroso (2008, p. 4): “[...] o ativismo judicial é uma atitude, a escolha de um modo específico e proativo de interpretar a Constituição, expandindo o seu sentido e alcance. Normalmente ele se instala em situações de retração do Poder Legislativo, de um certo descolamento entre a classe política e a sociedade civil, impedindo que as demandas sociais sejam atendidas de maneira efetiva. A idéia de ativismo judicial está associada a uma participação mais ampla e intensa do Judiciário na concretização dos valores e fins constitucionais, com maior interferência no espaço de atuação dos outros dois Poderes. A postura ativista se manifesta por meio de diferentes condutas, que incluem: (i) a aplicação direta da Constituição a situações não expressamente contempladas em seu texto e independentemente de manifestação do legislador ordinário; (ii) a declaração de inconstitucionalidade de atos normativos emanados do legislador, com base em critérios menos rígidos que os de patente e ostensiva violação da Constituição; (iii) a imposição de condutas ou de abstenções ao poder público, notadamente em matéria de políticas públicas.".
} 
As normas que definem de forma insuficiente um direito não são imediatamente aplicáveis na realidade social - não porque isso não seja desejável, mas porque é simplesmente impossível aplicar um direito sem conhecer as hipóteses e condições de sua incidência e as formas de seu exercício.

Trata-se de normas de baixa densidade normativa. Consequência da escolha do legislador constituinte de não concretizar suficientemente essas normas, tal como fez nas normas concretas e definidas, é a impossibilidade de aplicação imediata.

Nesse ponto é necessária particular atenção para não confundir duas situações juridicamente distintas. Por um lado, temos o imperativo constitucional da aplicabilidade imediata dos direitos e garantias fundamentais que cria uma vinculação direta e plena do destinatário passivo dos direitos e garantias. Por outro lado, temos o problema das condições impostas para o exercício de determinado direito ou garantia. Enquanto o destinatário passivo deve imediatamente se conformar com os mandamentos constitucionais implementando o direito "diretamente aplicável", o titular do direito, muitas vezes, não pode exercer esse direito de imediato.

Isso ocorre - além das hipóteses previstas no art. $6^{\circ}$ da $\mathrm{CF}$, no qual o constituinte se limitou a definir como "direitos sociais", entre outros, os direitos à moradia, educação, saúde, lazer - também quando o próprio texto constitucional estabelece condições para o exercício de certos direitos.

Portanto, defende-se aqui que a Lei Complementar federal é mesmo imprescindível, conforme o $\S 4^{\circ}$ do artigo 40 da $\mathrm{CF} / 88$, até para que o Poder Legislativo pudesse disciplinar aqueles critérios que visem o equilíbrio financeiro e atuarial dos RPPS, o que é uma matéria complexa, onde Coelho, Assad e Coelho (2006, p. 23) reafirmam a preocupação com tais critérios:

A preocupação é importante, uma vez que, a cada dia, aumenta o déficit do sistema previdenciário brasileiro, haja vista que as despesas são sempre superiores ao valor arrecadado. Por isso, correta a menção ao aspecto atuarial, para que a matemática, a estatística e a probabilística sejam utilizadas como base para o cálculo dos benefícios e serviços sem comprometer a viabilidade financeira da previdência social.

Daqui se extrai uma questão muito importante que é o conflito entre o interesse individual dos servidores públicos por sua aposentadoria especial e o interesse coletivo do Estado quanto ao sistema previdenciário do RPPS, e neste aspecto Dimoulis e Martins (2012, p. 169) apontam para o critério da proporcionalidade como método de intervenção em direitos fundamentais:

O vínculo do legislador aos direitos fundamentais, isto é, sua obrigação de observálos e respeitá-los ao estatuir regras gerais e abstratas, está intimamente ligado ao surgimento da ideia da proporcionalidade no direito constitucional. Com uma abrangência material que, em termos históricos, conheceu um grande crescimento nos dois últimos séculos, os direitos fundamentais representam, ao garantir a liberdade individual, verdadeiros óbices à ação do Estado que se dá em razão de interesses coletivos.

Para harmonizar o interesse individual como interesse coletivo, as Constituições modernas impõem, como se constatou acima, limites aos direitos fundamentais, limites esses que devem ser mais bem delineados pelo legislador ordinário. 
Ora, com a aposentadoria especial das pessoas com deficiência tal se deu somente a partir da LC 142, de 8/5/2013, para os servidores públicos que exerçam atividades de risco, ao menos a LC 51, de 20/12/1985 foi recepcionada, tratando da situação dos policiais, portanto, é chegada a hora da regulamentação, pelo Poder Legislativo, da aposentadoria especial dos servidores públicos, e que é parte do objetivo específico deste trabalho.

O ativismo judicial do STF, com a edição da Súmula Vinculante 33, tratou de forma igual 2 sistemas previdenciários distintos, o RGPS com critérios e regras próprias, inclusive com todo o seu custeio já regulamentado (Lei 8.212/91), e o RPPS com regras peculiares como: a idade mínima conjugada como tempo de contribuição do servidor público; um tempo mínimo de efetivo exercício no serviço público e outro no cargo efetivo em que se dará a aposentadoria; a forma de cálculo da renda inicial, onde os proventos de aposentadoria não poderão exceder a remuneração do respectivo servidor, no cargo efetivo em que se deu a aposentadoria.

A Proposta da Súmula Vinculante (PSV 45 $5^{25}$ ) do STF levou à discussão o posicionamento dos Ministros do STF, de aplicar a outras situações não tratadas nos 5.219 Mandados de Injunção que lá chegaram, com um entendimento mais alargado, já que 4.892, que representam $94 \%$, tratavam do $\S 4^{\circ}$ do artigo 40 da CF/88, até a dar uma espécie de eficácia vinculante às decisões desses mandados de injunção. Durante as discussões o Ministro Gilmar Mendes apontou que o locus para tal discussão era mesmo o Congresso Nacional dada a complexidade da matéria.

Destaca-se que, de todos os precedentes invocados para a edição da Súmula Vinculante 33, que em momento algum se cuidou dos critérios que visam o equilíbrio financeiro e atuarial dos RPPS, e no único onde foi suscitada de ofensa ao princípio constitucional da precedência de custeio (MI 925/DF), houve uma superação justificada no tocante à origem da fonte de custeio, já que esta incumbe mesmo unicamente ao ente público, porém de forma a observar tais critérios exatamente para a manutenção do sistema previdenciário.

\footnotetext{
${ }^{25}$ Disponível em: <http://www.stf.jus.br/arquivo/cms/jurisprudenciaSumulaVinculante/anexo/SUV_33 PSV_45.pdf>. Acesso em: 26 mar. 2016.
} 
Não é razoável que o legislador infraconstitucional tenha que observar tais princípios e critérios e que o Poder Judiciário numa decisão possa desobedecê-los. Não é sem propósito que a EC 20/1998 estabeleceu o equilíbrio financeiro e atuarial de forma explícita, como princípio constitucional para a organização dos RPPS, já que estes, em sua maioria, já existiam e se encontravam diante de uma situação de desequilíbrio estrutural crônico. Nogueira (2011, p. 82) aponta a razão de tal explicitação e cuidado do legislador constituinte derivado:

Portanto, "construir" o equilíbrio não foi apenas uma diretriz inovadora a ser observada pelos RPPS que viessem a ser instituídos, mas tarefa muito mais complexa, que implica "desconstruir" modelos e estruturas erroneamente consolidados há anos ou décadas. [...]

Porém, mantida a postura atual de não se tratar com a devida importância o equilíbrio financeiro e atuarial dos RPPS, essa situação irá se agravar no futuro, com prejuízo para a própria capacidade administrativa dos entes federativos. O desequilíbrio nas contas públicas, ocasionado pelo crescimento contínuo das despesas com pessoal, poderá comprometer a capacidade de efetivação das políticas públicas de interesse direto dos cidadãos, tais como saúde, educação, segurança e moradia, e conduzirá à necessidade imperiosa de severas reformas previdenciárias que ameaçarão os direitos dos servidores públicos.

Não à toa que o Projeto de Lei Complementar - PLP 472/2009 ${ }^{26}$, de autoria do Deputado Federal Arnaldo Faria de Sá (PTB-SP), apresentado em 28/4/2009, regulamentando o multicitado $\S 4^{\circ}$ do art. 40 da $\mathrm{CF} / 88$, dispondo sobre a concessão de aposentadoria a servidores públicos, nos casos de atividades exercidas exclusivamente sob condições especiais que prejudiquem a saúde ou a integridade física, encontra-se com prioridade de tramitação, mas aguardando parecer do Relator. A mens legis, segundo sua justificação ${ }^{27}$ era:

Desde a promulgação da Constituição Federal de 19988, os servidores públicos que exercem as suas atividades em condições que prejudicam a saúde vêm sendo impedidos de exercerem o seu direito a aposentadorias especiais em razão da inexistência de regulamentação da matéria.

Trata-se de injustiça flagrante que está a exigir correção há muito tempo, uma vez que os segurados do Regime Geral da Previdência Social vêm exercendo, normalmente, esse direito.

A situação tornou-se ainda mais injusta desde a promulgação da Primeira Reforma da Previdência - a Emenda Constitucional n. ${ }^{\circ}$ 20, de 1988 -, que tornou rígidas as normas para a aposentadoria dos servidores públicos. Ressalte-se, inclusive, que a citada emenda, buscando aproximar as normas de aposentadoria do RGPS e aquelas dos servidores públicos, alterou a redação do dispositivo que tratava da matéria, de forma a torná-lo absolutamente similar àquele que dispõe sobre o tema destinado aos segurados do Instituto Nacional do Seguro Social - INSS. [...]

\footnotetext{
${ }^{26}$ Disponível em: <http://www.camara.gov.br/proposicoesWeb/fichadetramitacao?idProposicao=432079\&ord=1>. Acesso em: 26 mar. 2016.

${ }^{27}$ Disponível em:

<http://www.camara.gov.br/proposicoesWeb/prop_mostrarintegra?codteor=650952\&filename=PLP+472/2009>. Acesso em: 26 mar. 2016.
} 
Assim, com vistas a suprir essa lacuna, apresentamos a presente proposição, regulamentando o $\$ 4 .^{\circ}$ do Art. 40 da Constituição e dispondo sobre a concessão de aposentadoria especial aos servidores titulares de cargos efetivos da União, dos Estados, do Distrito Federal e dos Municípios, incluídas suas autarquias e fundações, nos casos de atividades exercidas exclusivamente sob condições especiais que prejudiquem a saúde ou a integridade física.

Efetivamente, a presente proposição visa a adotar, para os servidores públicos, os mesmos critérios vigentes para a aposentadoria especial do RGPS. Trata-se parece, do mínimo que deve ser assegurado aos servidores públicos que têm a sua saúde deteriorada no exercício de atividades insalubres.

Pelo referido PLP 472/2009, o inciso III, do $§ 4^{\circ}$, do art. 40 da CF/88 ficará assim regulamentado:

\begin{abstract}
Art. 2. ${ }^{\circ}$ - A Aposentadoria especial será devida, uma vez cumprido o tempo mínimo de 10 (dez) anos de efetivo exercício no serviço público e 05 (cinco) anos no cargo efetivo em que se dará a aposentadoria, independentemente de idade, ao servidor que tiver trabalhado sujeito à condições especiais que prejudiquem a saúde ou a integridade física, durante 15 (quinze), 20 (vinte) ou 25 (vinte e cinco) anos, conforme o agente nocivo relacionado no Anexo I desta lei complementar.

Parágrafo Único - Os proventos de aposentadoria especial serão calculados na forma do estabelecido pelos $\S \S 2 .^{\circ}$ e $3 .^{\circ}$ do art. 40 da Constituição Federal.

Art. 3. ${ }^{\circ}$ - A aposentadoria especial somente será concedida na hipótese de o servidor ter exercido, durante os 15 (quinze), 20(vinte) ou 25(vinte e cinco) anos mencionados no Art. $2^{\circ}$, trabalho permanente e habitual, não ocasional nem intermitente, sujeito a condições especiais que prejudiquem a saúde ou a integridade física, assim entendidas as que o exponham aos agentes nocivos químicos, físicos, biológicos ou associação de agentes prejudiciais à saúde ou à integridade física, relacionados no Anexo I.
\end{abstract}

Portanto, para a obtenção da aposentadoria especial deverá ser cumprido um tempo mínimo de 10 (dez) anos de efetivo exercício no serviço público e 05 (cinco) anos no cargo efetivo em que se dará a aposentadoria, independentemente de idade, ao servidor que tiver trabalhado sujeito às condições especiais que prejudiquem a saúde ou a integridade física, durante 15 (quinze), 20 (vinte) ou 25 (vinte e cinco) anos, conforme o agente nocivo relacionado naquele projeto de lei complementar.

Assim, não poderia o STF superar a exigência de lei complementar prevista tanto no $\S 4^{\circ}$ do art. 40 da CF/88 quanto no parágrafo único do artigo $5^{\circ}$ da Lei 9.717/1998, que trata das regras gerais para a organização e o funcionamento dos RPPS dos servidores públicos das 3 esferas de poder. Diferentemente de normas de eficácia plena e aplicabilidade imediata, a norma constitucional que prevê a aposentadoria especial para o servidor público tem eficácia limitada, e, conforme ensinam Souza Neto e Sarmento (2014, p. 372) não receberam a normatividade suficiente para a produção de todos os seus efeitos, portanto: "essas normas carecem de regulamentação infraconstitucional para se tornarem plenamente operativas.”.

Reitere-se que quando o STF editou a Súmula Vinculante 33, utilizando-se do método hermenêutico tópico-problemático para a solução do caso concreto, conseguiu 
resolver o problema dos servidores públicos, mas criou um problema maior para a manutenção e sustentabilidade do RPPS, porque os Ministros não se preocuparam com os critérios que visam o equilíbrio financeiro e atuarial do regime próprio, numa inconstitucionalidade flagrante, o que o citado PLP 472/2009 prevê, porque um desequilíbrio neste sistema previdenciário seria uma catástrofe para milhares de servidores públicos brasileiros que sobrevivem dos proventos de seus benefícios previdenciários.

Como todo estudo científico e crítico deve propor uma solução ao problema sob análise, com relação ao RPPS, sugere-se que no próximo estudo atuarial considerem-se as concessões dessas aposentadorias especiais, e o reflexo na massa de benefícios, porque ao permitir a aposentadoria mais cedo (aos 15, 20 ou 25 anos de exposição a fatores de risco), isto impactará o caixa dos RPPS. E se a questão da contrapartida parece ter sido superada, o equilíbrio financeiro e atuarial não foi, pondo em risco a solvabilidade do sistema, e a Súmula Vinculante 33 poderá exatamente por em risco todo o sistema, tal qual a síndrome de Frankenstein, onde a criatura destruiu o criador.

O que se quer e espera é que direitos fundamentais sejam garantidos, porém, não em detrimento de toda a sociedade ou, ao menos, de todo um regime próprio de previdência social mantido pelos entes públicos.

\section{CONSIDERAÇÕES FINAIS}

As alterações promovidas pelos legisladores constituintes originários e derivados criaram regimes previdenciários com natureza eminentemente contributiva, mas com critérios que preservem o equilíbrio financeiro e atuarial de cada regime, seja o geral ou o próprio dos servidores públicos. Para isto, obrigou que o legislador infraconstitucional igualmente devesse respeito a esta criação, para a manutenção e solvabilidade dos regimes. E, diante das mudanças econômico-sociais passadas pelo Brasil, também dotou o legislador de instrumentos para a efetiva realização desse equilíbrio.

É verdade que o legislador infraconstitucional demora na regulamentação de alguns direitos, que inclusive são fundamentais, mas diante da complexidade de alguns temas, isto é inevitável, foi assim com a aposentadoria especial das pessoas com deficiência. Porém, quando decisões judiciais que, objetivando efetivar estes direitos, descuidam dos princípios constitucionais e da técnica específica e necessária à manutenção e solvabilidade do sistema previdenciário, acabam por violar o interesse coletivo da manutenção do sistema 
previdenciário, por infringir o princípio da separação dos Poderes e o próprio Sistema de Seguridade Social brasileiro, em claro ativismo judiciário que não se preocupou com as consequências de tais decisões.

Os mandados de injunção que serviram de precedentes para a criação da Súmula Vinculante 33 e as discussões dos Ministros do STF quando da Proposta da Súmula Vinculante, demonstraram que não foram analisados todos os princípios, critérios e aspectos que o Direito Previdenciário lança mão para a concessão de um benefício previdenciário. E, conforme visto, até mesmo direitos fundamentais podem ser ponderados pelo Estado, num critério de proporcionalidade entre os interesses particulares e o interesse coletivo. Portanto, acredita-se ter ficado demonstrado que ao invés de uma aparente solução, a Súmula Vinculante 33 criou um grave problema financeiro e atuarial nos RPPS, quando os segurados requererem suas aposentadorias baseados nela, diante dos critérios distintos dos que o legislador infraconstitucional está por estabelecer, como demonstrado no Projeto de Lei Complementar PLP 472/2009, regulamentando o art. 40, $\S 4^{\circ}$, III, da CF/88.

É fato que o STF não se preocupou com o equilíbrio financeiro e atuarial nos RPPS, que faz com que os benefícios devidos por lei sejam satisfeitos no presente e no futuro, ao contrário, em momento algum isto chegou a ser discutido pelos Ministros, e um assunto complexo assim merece mesmo ser discutido pelo Poder Legislativo, mormente diante das consequências que impactarão nos RPPS e em toda a sociedade, que em última instância, financia parte dos benefícios do setor público, daí o interesse coletivo e sua supremacia sobre estes direitos individuais.

Tomara que, à semelhança do filme Frankenstein, a criatura não destrua o seu criador, porque os sistemas de Previdência pública e privada no Brasil vêm passando por constantes reformas, dentre elas a EC 20/1998 que buscou dar um equilíbrio financeiro e atuarial no sistema, procurando não só evitar o aumento do déficit e das despesas públicas, mas garantir uma Previdência Social segura para os servidores públicos e trabalhadores do Brasil, o que está conforme os objetivos fundamentais de nossa República, para a construção de uma sociedade livre, justa e solidária, objetivos estes que devem sempre nortear tanto o legislador quanto o próprio intérprete da norma, com vistas à edificação e solidificação de um verdadeiro Estado Social e Democrático de Direito. 


\section{REFERÊNCIAS BIBLIOGRÁFICAS}

ARAÚJO, Luiz Alberto David; NUNES JÚNIOR, Vidal Serrano. Curso de direito constitucional. 20. ed. rev., atual. até a EC 90 de 15 de setembro de 2015. São Paulo: Editora Verbatim, 2016.

BALERA, Wagner. Sistema de seguridade social. 6. ed. São Paulo: LTr, 2012.

BARROSO, Luís Roberto. Ano do STF: Judicialização, ativismo judicial e legitimidade democrática. In: Revista Consultor Jurídico, 22 dez. 2008. Disponível em: <http://www.conjur.com.br/2008-dez-22/judicializacao_ativismo_legitimidade_democratica>. Acesso em: 29 mar. 2016.

BERWANGER, Jane Lucia Whilhelm. Previdência rural: inclusão social. 2. ed. Curitiba: Juruá, 2008.

CAMPOS, Marcelo Barroso Lima Brito de. Regime próprio de previdência social dos servidores públicos. 4. ed. Curitiba: Juruá, 2012.

CASTRO, Carlos Alberto Pereira de; LAZZARI, João Batista. Manual de Direito Previdenciário. 9. ed. São Paulo: LTr, 2008.

COELHO, Fábio Alexandre; ASSAD, Luciana Maria; COELHO, Vinícius Alexandre. Manual de direito previdenciário: benefícios. São Paulo: Editora Juarez de Oliveira, 2006.

DIMOULIS, Dimitri; MARTINS, Leonardo. Teoria geral dos direitos fundamentais. 4. ed. rev., atual. e ampl. São Paulo: Atlas, 2014.

HORVATH JÚNIOR, Miguel. Direito previdenciário. 7. ed. São Paulo: Quartier Latin, 2008 .

MARTINS, Sérgio Pinto. Direito da seguridade social. 34. ed. São Paulo: Atlas, 2014.

Fundamentos de direito da seguridade social. 13. ed. São Paulo: Atlas, 2012.

NOGUEIRA, Narlon Gutierre. O equilíbrio financeiro e atuarial dos RPPS: de princípio constitucional a política pública de Estado. In: Revista do Tribunal de Contas do Estado de Minas Gerais. V. 81, n. 4, ano XXIX, pp. 75-91, out/nov/dez. 2011. Disponível em: <http://revista.tce.mg.gov.br/Content/Upload/Materia/1333.pdf>. Acesso em: 27 mar. 2016.

SOUZA NETO, Cláudio Pereira de; SARMENTO, Daniel. Direito constitucional: teoria, história e métodos de trabalho. 2. ed. Belo Horizonte: Fórum, 2014.

TORRACA, Sylvia Pozzobon. Princípio do equilíbrio financeiro e atuarial - uma breve análise do princípio insculpido no caput do artigo 201 da Constituição Federal. In: Âmbito Jurídico, Rio Grande, XIII, n. 78, jul 2010. Disponível em: <http://www.ambito-juridico.com.br/site/index.php?n_link=revista_artigos_leitura\&artigo_id =7908>. Acesso em: 27 mar. 2016. 
VIEHWEG, Theodor. Tópica e jurisprudência: uma contribuição à investigação dos fundamentos jurídico-científicos. Tradução da 5. ed. Alemã, rev. e ampl., de Prof ${ }^{a}$ Kelly Susane Alflen da Silva. Porto Alegre: Sergio Antonio Fabris Ed., 2008. 